ppi $201502 Z U 4645$

Esta publicación cientifica en formato digital es continuidad de la revista impresa ISSN-Versión Impresa 0798-1406 / ISSN-Versión on line 2542-3185Depósito legal pp

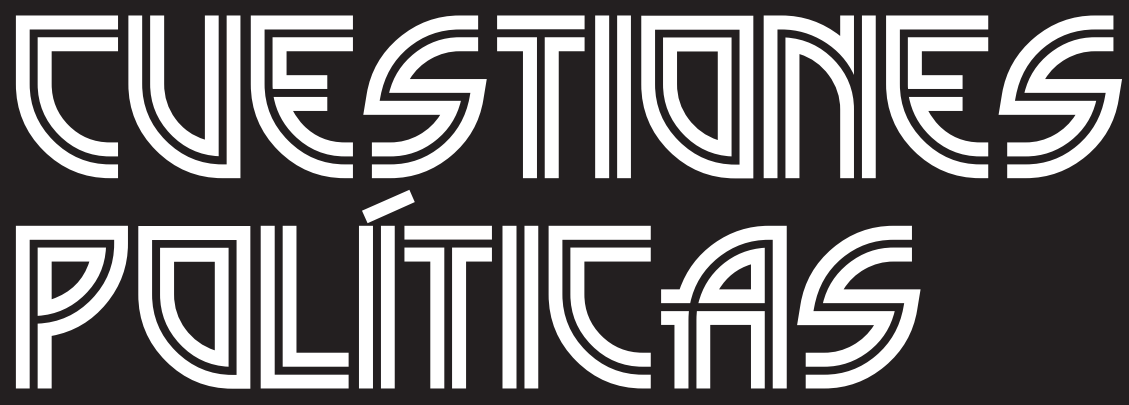

Instituto de Estudios Políticos y Derecho Público "Dr. Humberto J. La Roche' de la Facultad de Ciencias Jurídicas y Políticas de la Universidad del Zulia Maracaibo, Venezuela
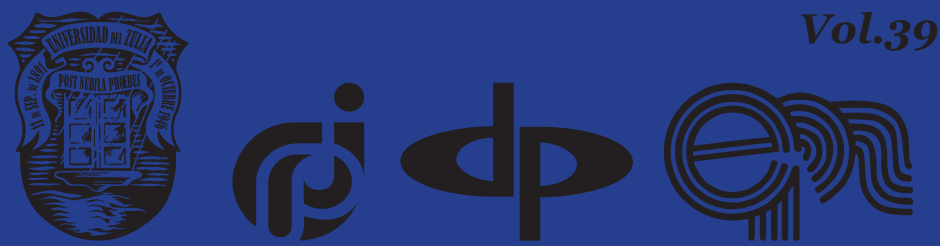


\title{
Study of The Transformation of Social and Labor Relations in The Conditions of Pension Reform: Aspect of Digital Axiology
}

\author{
DOI: https://doi.org/10.46398/cuestpol.3968.41
}

\begin{abstract}
Apenko Svetlana Nikolaevna *
Kiriliuk Olga Mikhailovna **

Legchilina Elena Yurevna ***

Tsalko Tatiana Valerevna ${ }^{* * * *}$
\end{abstract}

\section{Abstract}

He was intended to understand the process of transforming social and labor relations in the context of the implementation of pension reform in Russia, taking into account the axiological aspects, in particular «digital axiology». Its objective is to identify the impact of digitization on changes in industrial relations in the context of pension reform. The theoretical and methodological basis of research is based on an interdisciplinary system approach and generational value theory. An economic analysis is performed, along with the grouping of empirical data and digitization rates are presented. A survey of more than 6,000 people was also conducted, the theme of which was to assess the impact of the Russian Federation's pension reform on social and labor relations, economic growth and the quality of life of the population. The article examines cardinal changes in the social and employment relationships of people of pre-retirement age in the context of digitization. It is concluded that the main problems of the development and formation of digital axiology among the pre-retired demand a set of political transformations.

Keywords: digitization; digital axiology; digital economy; transformation of social and labor relations; planned reform.

* Doctor of economic sciences, professor, Dostoevsky Omsk State University, head of the department "Management and marketing" Omsk State Transport University, professor of the department "Management, marketing and commerce Omsk, Russian Federation. ORCID ID: https://orcid. org/oooo-ooo2-7618-3961. Email: apenkosn@yandex.ru

** Candidate of economic sciences, Omsk State Transport University, docent of the department "Management, marketing and commerce". Omsk, Russian Federation. ORCID ID: https://orcid. org/oooo-0001-7892-6987. Email: olgaomgau@yandex.ru

*** Candidate of economic sciences, associate professor, Omsk State Transport University, head of the department "Management, marketing and commerce". Omsk, Russian Federation. ORCID ID: https:// orcid.org/oooo-0002-9091-0600. Email: legcelena@yandex.ru; e.legchilina755@gmail.com

***** Candidate of economic sciences, Omsk State Transport University, docent of the department "Management, marketing and commerce". Omsk, Russian Federation. ORCID ID: https://orcid. org/oooo-ooo3-1898-5963. Email: bt_tv@mail.ru 


\section{Estudio de la transformación de las relaciones sociales y laborales en las condiciones de la reforma de pensiones: aspecto de la axiología digital}

\section{Resumen}

El estudio tuvo el propósito de comprender el proceso de transformación de las relaciones sociales y laborales en el contexto de la implementación de la reforma de las pensiones en Rusia, teniendo en cuenta los aspectos axiológicos, en particular la "axiología digital". Su objetivo es identificar el impacto de la digitalización en los cambios en las relaciones laborales en el contexto de la reforma de las pensiones. La base teórica y metodológica de la investigación se basa en un enfoque de sistema interdisciplinario y la teoría de valores de generaciones. Se realiza un análisis económico, junto a agrupación de datos empíricos y se presentan índices de digitalización. Se realizó también una encuesta a más de 6.000 personas, cuyo tema fue evaluar el impacto de la reforma de las pensiones de la Federación de Rusia en las relaciones sociales y laborales, el crecimiento económico y la calidad de vida de la población. El artículo examina los cambios cardinales en las relaciones sociales y laborales de las personas en edad de prejubilación en el contexto de la digitalización. Se concluye que los principales problemas del desarrollo y formación de la axiología digital entre los prejubilados demandan de un conjunto de transformaciones políticas.

Palabras clave: digitalización; axiología digital; economía digital; transformación de las relaciones sociales y laborales; reforma previsional.

\section{Introduction}

Modern trends in the economy are characterized by large-scale digitalization processes. Digitization is radically changing the business landscape in all industries. To stay competitive, companies around the world are increasingly investing in digital transformation. Most large companies and holdings have developed programs and concepts for digitalization. For example, PJSC Rosseti is planning to carry out digital transformation of all business processes in the amount of more than 1.3 trillion rubles. (The Concept of Digital Transformation of Pjsc Rosseti 2030, 2018). In addition, digitalization extends to the system of social and labor relations. An example is digital HR platforms aimed at automating employee relationship processes and all HR management processes implemented by large enterprises and organizations. The global nature and significance of digitalization processes for Russia is indicated in the Decree of the President of the Russian Federation of July 21, 2020 No. 474 "On the 
Apenko Svetlana Nikolaevna, Kiriliuk Olga Mikhailovna, Legchilina Elena Yurevna y Tsalko Tatiana Valerevna

national development goals of the Russian Federation for the period up to 2030" (Decree Of The President Of The Russian Federation, 2020).

The ongoing digital transformation of socio-economic processes, aimed at economic growth and improving the quality of life, determines fundamental changes in the content and nature of labor, which leads to the transformation of social and labor relations, the emergence of new remote, non-standard forms of labor relations. These processes lead not only to the development of a new employee value system, but also to the formation of a new axiology in economics - "digital axiology" (Timofeev, 2019). A new meaning is given to business procedures, the relationship between an employee and an employer, production and technological, economic, social and communication processes are accelerated.

Digitalization processes in Russia are superimposed on fundamental institutional changes in the pension system in terms of raising the retirement age, which is due to the aging of the labor force. Thus, according to international (Bersin and Chamorro-Premuzic, 2019) and Russian studies (GKS, 2019; Statistical Handbook, 2019), next year the number of people aged 60 and over will exceed the number of children under the age of five, and by 2025 it is expected that 25\% of workers in Europe, the United States and Russia will be over 55 years old. That is, this group of workers is the fastest growing in almost all countries.

The noted tendencies cause certain problems and contradictions in the social and labor sphere. So, on the one hand, the digital economy requires mobile creative workers who are ready and able to work in a highly dynamic digital environment, possessing the necessary digital competencies, for which information and digital technologies are one of the basic instrumental values (values-methods). On the other hand, the pension reform keeps the older generation on the labor market, who have different basic instrumental values. Are pre-retirees ready and able to change in the context of digitalization and how economically feasible is the "digital transformation" of working pre-retirees?

A number of Russian and foreign studies indicate that enterprises (employers) do not want to enter into labor relations with older workers and pre-retirees. Thus, according to research by the Deloitte agency, which surveyed more than 10 thousand large companies, more than twothirds of companies considered old age a competitive disadvantage, twothirds of people aged 45 to 70 years old faced age discrimination (Bersin and Chamorro-Premuzic, 2019). That is, workers over 50 years old are considered by most enterprises to be less capable, less flexible (able to adapt) or less ready to innovate and digitalize than younger employees, which is confirmed by the authors' studies. A survey of business leaders conducted by the authors of this study revealed employers' preferences for hiring employees under the age of 50 . According to employers, workers 
over 50 years old have low motivation to perform labor operations, have low or no digital skills and competencies, and are also prone to professional burnout.

Accordingly, these debatable questions about the possible transformation of the labor values of older workers, about the formation of the "digital axiology" of pre-retirees determine the relevance of the research topic.

\section{Literature Review}

The ongoing transformation of the value space in social and labor relations is a consequence of institutional changes in the social sphere and turbulence of socio-economic development, and, from our point of view, directly affects the quality of life of the population and the strategic stability of the country's socio-economic system (Legchilina, 2019).

It should be noted the pluralism of theories of transformation of socioeconomic systems (the theory of neocapitalism, the theory of staged economic growth, the theory of industrial, post-industrial information society, the theory of convergence, the theory of the technotronic era, new institutionalism, the theory of quality of life, and others).

Problems of social and labor relations and their transformation are presented in the works of Russian scientists and foreign studies Polovinko V.S. (Polovinko, 2015), Medvedeva T.A. (Medvedeva, 2013), Nehoda E.V. (Nehoda, 2013), (Legchilina, 2019), Buchele, R., Christiansen J. (Buchele and Christiansen, 1999), (Howe, 2017) and many others.

There is a diversity and pluralism of research in the field of labor values (Cutcher-Gershenfeld and Isaac, 2018), (Helfen et al., 2018) and others. The problems of pension reform, the positive effects and the likely risks of raising the retirement age are considered in the works of Russian scientists and foreign studies Yu. M. Gorlin, T.M. Malevoy, V. Yu. Lyashok (Gorlin et al., 2018), A.K. Soloviev (Soloviev, 2015), I. F. Zhukovskaya (Zhukovskaya, 2018), A. Albanese, B. Cockx (Albanese and Cockx, 2019), S. Etgeton (Etgeton, 2018), J. Geyer, P. Haan, A. Hammerschmid, M. Peters (Geyer et al., 2020), M. Sánchez-Romero, J. Sambt, A. Prskawetz (Sánchez-Romero et al., 2013), T. Vigtel (Vigtel, 2018).

The theoretical and methodological foundations of the research were based on an interdisciplinary approach, including theories and methodologies of axiology, labor economics, etc. (Rokeach, 1973). In social and labor relations (SRT), values-goals are internal final motivational semantic tasks that the parties wish to achieve. Values-methods in SRT are considered as means of achieving value-goals. That is, for example, "the result of labor" refers to the value-goals, the means of labor and the form of SRT - to the values-methods. In accordance with this theory, values-goals 
are decisive, system-forming in social and labor relations and are more resistant to changes. Values-ways are determined by the development of society and the socio-economic system. Therefore, in the context of digitalization, within the framework of this study, we will consider changes in values-methods in the context of the formation of a "digital axiology" of labor in the social and labor relations of pre-retirees. Then we will take A.V. Timofeev as a basis for the study (Timofeev, 2019), which defines "digital axiology" (digitalization as a value) as a new nature and structure of values in cultural, socio-economic reality, which is based on the digitalization of the economy and society. At the same time, the concept of "value" is considered by the authors in classical dialectics as the significance of phenomena and objects of reality.

\section{Materials and methods}

Digitalization not only changes the structure of the labor market and causes the emergence of some professions and the exit from the market of others, but also leads to an increase in labor productivity due to the automation of labor processes, and a reduction in personnel. On the other hand, there is an increase in the life expectancy of the population and the burden on the pension system, which forces employers to keep jobs for workers of pre-retirement and retirement age. The retirement age for men and women has been raised.

According to Russian legislation (Federal Law "On Employment of the Population in the Russian Federation"), persons of pre-retirement age are now considered citizens for five years before the onset of the age that gives the right to an old-age insurance pension, including those assigned ahead of schedule.

To make the innovations carried out as painlessly as possible into the life of Russians, the Government of the Russian Federation has strengthened the legal position of pre-retirees at the legislative level.

The efforts of all branches of government: legislative, executive, judicial, are currently aimed at protecting the rights of this category of persons. Local self-government bodies also play a huge role.

For this category of workers, measures of state support and protection are provided.

The Ministry of Labor and Social Protection of the Russian Federation has developed special program activities that include retraining and advanced training courses that allow people of pre-retirement age to master new professions, while remaining in demand on the market. 
In 2019, within the framework of the RFBR grant, a survey was conducted of about 6,000 respondents, the purpose of which was to assess the impact of the pension reform of the Russian Federation on social and labor relations, economic growth, and the quality of life of the population (Apenko et al., 2019).

Research methodology. The field qualitative and quantitative research was carried out by a survey method using a questionnaire developed by the authors, consisting of 18 questions in paper form and by reference in the online mode. The formulated purpose of the survey is to assess the impact of the pension reform of the Russian Federation on social and labor relations, economic growth and the quality of life of the population.

For the survey, the general population was selected - the economically active population of the Russian Federation. The sample was formed from the general population in a random way. The number of respondents included urban and rural residents of both sexes, economically active population, with different income levels and without it, representatives of different social statuses.

When analyzing the data, the following tools were used: arithmetic mean, minimum and maximum values, metric scales, fashion, frequency, valid percentage, variance.

The conclusions obtained in the course of the study made it possible to assess the opinions of people regarding the pension reform of the Russian Federation, labor values and satisfaction with working conditions, labor behavior during the period of active digitalization, as well as the socio-psychological climate in the work collective towards persons of preretirement and retirement age. The authors' interest lies in expanding the scientific concept and views in the field of building a model for transforming social and labor relations that affect the quality of life of the population and economic growth within the framework of the system-axiological approach.

In addition, a survey was conducted of workers of pre-retirement age in a number of divisions of the Russian Railways holding company. A total of 760 people were interviewed, including 515 workers, 245 specialists and employees. The survey was conducted from April to September 2019.The source of the questionnaire for the respondents was the place of work / study (90\%), employment centers (2.6\%); Pension fund branches (2.5\%), Internet (1.9\%), acquaintances (2\%), MFC branches (about 1\%). The majority of the survey was women. The average age of the respondents is 39 years. In terms of employment status, they are mostly specialists (41.3\%). The average monthly income of the respondents is 19 thousand rubles. The geography of respondents is represented by urban and rural residents of the Russian Federation. 
Apenko Svetlana Nikolaevna, Kiriliuk Olga Mikhailovna, Legchilina Elena Yurevna y Tsalko Tatiana Valerevna

Study of The Transformation of Social and Labor Relations in The Conditions of Pension Reform: Aspect of Digital Axiology

\section{Results and discussion}

This study focuses on workers who are five years or less before retirement, that is, relative to 2020 and taking into account the pension reform, these are men born in 1960-1963 and women born in 1965-1969. Let's call this category pre-retirees. The authors of the designated problematic in the study of digital axiology passed it through the Strauss-Hove theory (Kulakova, 2018). Note that, in accordance with the value system of Strauss generations, pre-retirees occupy an intermediate position between "baby boomers" and generation X, for whom digitalization is more of a necessity than a value. Thus, this generation, which does not attach importance and importance to computer and information technologies, is ready to adapt to a rapidly changing environment, including digitalization. The labor axiology of pre-retirees was formed in the post-war years, characterized by numerous reforms, disasters, transformations and wars (bipolar world, Chernobyl accident, Afghan war, restructuring to market relations, default, privatization and many others) (Ozhiganova, 2015; Stepanova and Trishina, 2019). Accordingly, this generation is characterized by a willingness to change, technical literacy, the ability to rely only on themselves, and the ability to adapt to a changing world (Shamis and Antipov, 2016). These conclusions are confirmed by the author's research.

As noted above, a survey was conducted in 2019 aimed at assessing the impact of the pension reform of the Russian Federation on social and labor relations, economic growth and the quality of life of the population. According to the survey, in the case of the introduction of digital technologies, modern information software based on digital, at the workplace, 5,065 people are ready to undergo training and continue to work. (85.2\%); will stop working and retire (in case of retirement age) - 655 respondents (11\%); will change the place of work - 215 people. (3.6\%) (Apenko et al., 2019).

Thus, after the survey, the following conclusions were made.

Half of the respondents (49.9\%) are fully aware of the pension reform of the Russian Federation, the essence of which is the increase in the retirement age, a little less (46.7\%) have heard, but do not know the details.

According to the respondents, the main goal of the pension reform proposed in the questionnaire is to increase the income of the state budget through tax payments of working citizens (40.8\%). With the aim of the reform "improving the quality of life of citizens, since the income of working citizens is higher than the size of the pension of pensioners", $43.8 \%$ of respondents fully disagree.

When introducing information technologies, modern software and digitalization elements, $85.2 \%$ of respondents are ready to undergo training and continue to work. The remaining $11 \%$ of respondents will either stop working and retire or change their place of work (3.6\%). 
For the respondents - people of pre-retirement age and working pensioners - labor relations with employers have not changed. Such answers are $80 \%$. Transferred to a fixed-term employment contract $8.7 \%$ of responses. Other answer options (dismissal, layoffs, reduced job responsibilities) take less than $2 \%$.

Respondents - people of pre-retirement age / working pensioners assessed a positive attitude towards themselves - 34.8\% of responses; rather positive - $22.6 \%$; indifferent - $33 \%$; rather negative, tension is felt $2.5 \%$; negative because of obstacles to the career of other employees $-3.4 \%$.

$90.9 \%$ of the respondents did not change their attitude to their official duties since the beginning of the pension reform. Summing up, it should be noted that the data presented demonstrate a clear tendency of ambiguous opinions of residents of the Russian Federation regarding the increase in the retirement age and the goals of the pension reform. The attitude of people of different generations to the pension reform does not have a pronounced negative connotation. The change in social and labor relations affected only a part of employed citizens of pre-retirement and retirement age. A positive trend is the desire for advanced training in the context of the digitalization policy.

In addition, a survey of workers of pre-retirement age in a number of divisions of the Russian Railways holding company made it possible to draw the following conclusions. Thus, more than $37.4 \%$ of respondents spoke about the likelihood of digitalization of the workplace in the next two years. All respondents (100\%) expressed the likelihood of changes in the labor situation in connection with the digitalization of the workplace. Opinions were distributed as follows: $17.1 \%$ expect a demotion; $42.4 \%$ see the need and are ready to master new digital competencies through advanced training; $9.4 \%$ are ready to change their profession; job losses are expected to be about $10.7 \%$. Only $9.1 \%$ of the respondents expressed their readiness to switch to flexible forms of social and labor relations, including self-employment. Only $15.5 \%$ of respondents expect higher wages from digitalization of the workplace in excess of the bonuses provided for by the collective agreement.

Accordingly, it can be concluded that pre-retirees are ready to learn digital technologies, to form digital competencies, and to develop digital literacy. On the other hand, employers are not ready to invest in the training of pre-retirees and the formation of their digital axiology, giving preference to generation Y workers. The "digital axiology" of generation Y workers is being formed much faster, since it is this generation that creates digital technologies. Skepticism and inability to obey, the desire for immediate reward and interesting work are characteristic of the "gamers". 
Apenko Svetlana Nikolaevna, Kiriliuk Olga Mikhailovna, Legchilina Elena Yurevna y Tsalko Tatiana Valerevna

The subject of modern discussions in the field of formation and development of digital axiology of pre-retirees is the problem of the value of intelligence, work experience and digital competencies. It should be noted that the foundation of digitalization, digital economy and artificial intelligence was laid by pre-retirees who strive to adapt and survive in difficult socio-political and economic conditions. On the other hand, preretirees do not have sufficient digital literacy and digital competencies. Foreign researchers also conduct research on age discrimination among employees (Carlssona and Eriksson, 2019).

Digital competencies are defined in this study as well-trained, deeply rooted procedures for using digital devices, communication applications, and networks to access and control information. Digital competencies include the effective use of various modern computing tools; confident use of software and hardware to search, extract, copy, interpret and exchange digital data; analysis of digital data; creation and application of computing tools for processing industry data for the purpose of making decisions; using online tools for team projects.

A number of scientists are concerned about the problem of weakening and even devaluation of natural intelligence in favor of artificial intelligence. According to experts, this problem mainly affects generations $\mathrm{Z}$ and $\mathrm{Y}$, which, thanks to the development of artificial intelligence, may lose motivation for development E. Shamis, A. Antipov (Shamis and Antipov, 2016), T. Stepanova, O. Trishina (Stepanova and Trishina, 2019).

In addition, studies of the digital axiology of pre-retirees have shown the existence of a "digital barrier", which is caused by the presence of socioeconomic inequality, low incomes of a number of categories of pre-retirees and rural areas, which limits access to digital technologies (for example, lack of a computer and access to the Internet (for example, about $40 \%$ of pre-retirees do not have access to the Internet; leads to anxiety when interacting with new digital technologies due to the lack of digital literacy and skills, etc.

The digital literacy index of Russians in the 1st quarter of 2020 was 58 points on a scale from o to 100 (the index was calculated using the Digcomp methodology). Only $31 \%$ of Russians - one in four - have digital skills. It should be noted that the annual internal costs for the development of the digital economy in Russia amount to $3.6-3.7 \%$ of GDP. Russia ranks $45^{\text {th }}$ in the world in terms of the development of information and communication technologies (ICT). The Business Digitalization Index (hereinafter referred to as the Index), developed by the Institute for Statistical Studies and Economics of Knowledge of the Higher School of Economics, characterizes the speed of adaptation of organizations to digital transformation. The index is calculated for organizations in the business sector of Russia, Turkey, Japan, the Republic of Korea, as well as European countries. According to 
the National Research University Higher School of Economics, the Index in Russia is one of the lowest among the countries included in the study. In 2018, the Index was 31\% against 28\% in 2017 (Fig. 1).

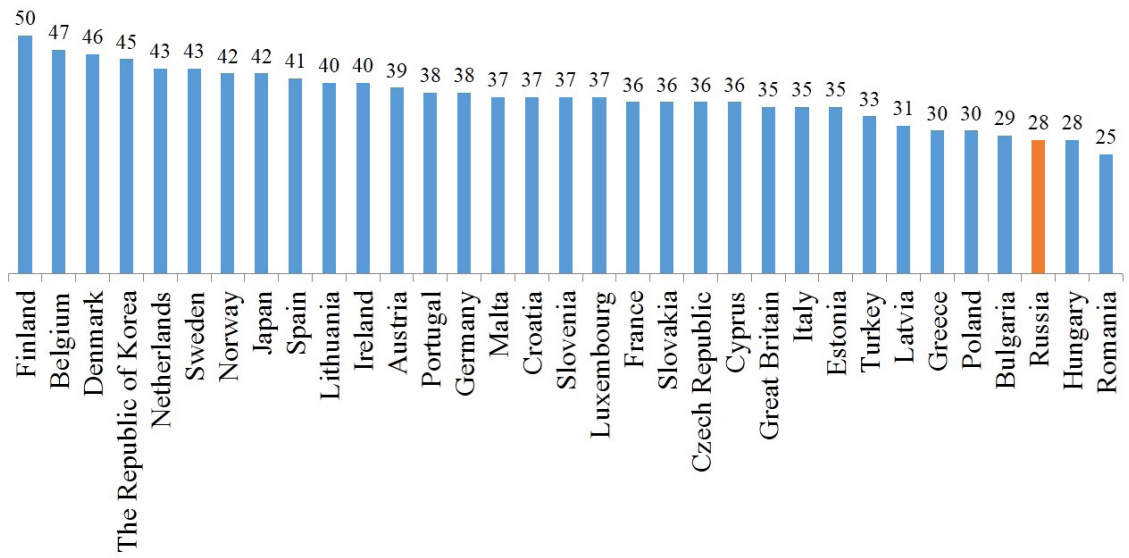

Figure 1. Business digitalization index in Europe and Russia Source: (National, 2018).

Analysis of the intensity of the use of digital technologies in Russia taken into account when calculating the Index shows that broadband Internet access is used by $86 \%$ of organizations, cloud services - 27.6\%, ERP systems - 21.6\%, e-commerce - 19.9\%. RFID technologies - 6\% (Table 1).

\begin{tabular}{|c|c|c|c|c|c|c|c|c|c|c|c|}
\hline $\begin{array}{c}\text { Business } \\
\text { digitalization } \\
\text { index }\end{array}$ & $\begin{array}{c}\text { Broadband } \\
\text { internet }\end{array}$ & \multicolumn{2}{|c|}{$\begin{array}{c}\text { Cloud } \\
\text { services }\end{array}$} & \multicolumn{2}{|c|}{$\begin{array}{c}\text { RFID } \\
\text { technology }\end{array}$} & \multicolumn{2}{|c|}{$\begin{array}{c}\text { ERP } \\
\text { systems }\end{array}$} & \multicolumn{2}{|c|}{$\begin{array}{c}\text { Electronic } \\
\text { commerce }\end{array}$} \\
\hline 2017 & 2018 & 2017 & 2018 & 2017 & 2018 & 2017 & 2018 & 2017 & 2018 & 2017 & 2018 \\
\hline 28 & 31 & 82 & 86 & 23 & 27,1 & 6 & 6,8 & 19 & 21,6 & 12 & 19,9 \\
\hline
\end{tabular}

Table 1. Business digitalization index in Russia in 2017-2018

Source: (National, 2018).

It should be noted that the international index of the digital economy of society in Russia also remains at a fairly low level. In 2019, it amounted to $0.45 \mathrm{pp}$ (Fig. 2). 
Apenko Svetlana Nikolaevna, Kiriliuk Olga Mikhailovna, Legchilina Elena Yurevna y Tsalko Tatiana Valerevna

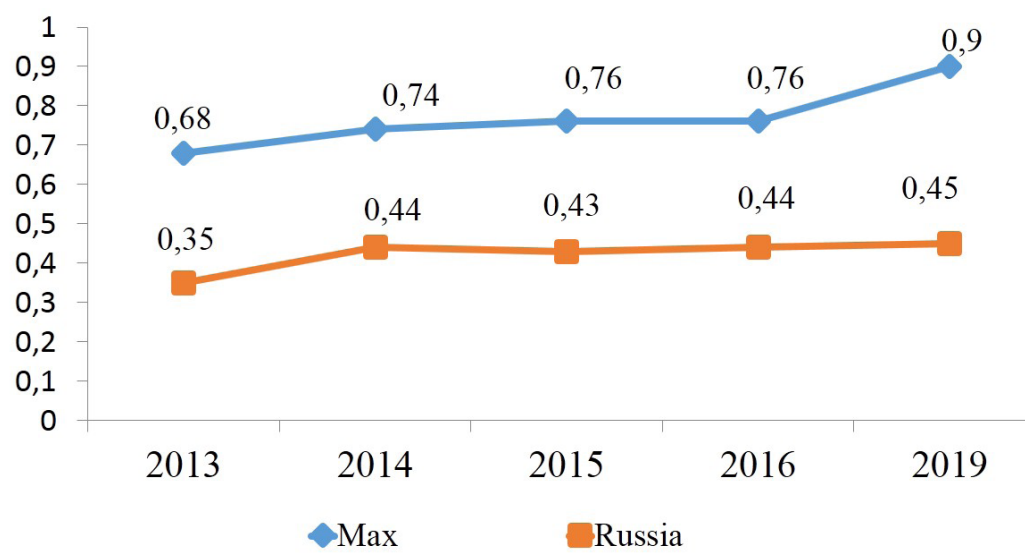

Figure 2. Dynamics of the international index of the digital economy of society

(Bakumenko and Minina, 2020).

Thus, the research results have shown the underdevelopment of digital technologies in Russian society, respectively, "digital axiology" in Russian society is at the stage of formation, in particular among people of pre-retirement age. In addition, studies have shown the reluctance and unwillingness of employers to invest in solving this problem, especially in relation to pre-retirees.

The authors note that numerous international studies of innovative transformations in various fields speak of the need for "team thinking". The vast majority of innovations, scientific advances are the result of coordinated, human activities or people working together as a whole. Maximizing the effectiveness of teamwork is an increase in cognitive diversity (Anshina, 2019). The results of these studies indicate the need to attract older workers to develop innovative products.

Taking into account the global trends of population aging, the extension of the retirement age, according to the authors, is economically justified for the country. The authors believe that the formation of "digital axiology" among pre-retirees should be based on the balance of interests of the parties in social and labor relations. That is, in order to extract the maximum value that pre-retirees can bring to the enterprise, companies need to transform social and labor relations. The author's approach to the formation of "digital axiology" within the framework of the transformation of the system of social and labor relations is based on the concept of lifelong learning and the 
formation (change) of values for several generations. Based on the works of L. Gratton and E. Scott, the authors recommend moving from a three-stage life, consisting of education, career and retirement, to a multi-stage path, forming a communicative and analytical axiology. The authors' conclusions are confirmed in the forecasts of the Pew Research Center (Lloyd, 2018) and in the studies of Russian scientists (Stuken and Korzhova, 2019), who say that the most valuable skills in the future will be those that machines cannot easily reproduce, for example, creativity, critical thinking, emotional intelligence, adaptability and collaboration.

\section{Conclusions}

Thus, the "digital axiology" of pre-retirees is formed under the influence of the corresponding economic and political situation, leading to a change in the digital culture of pre-retirees as a condition of "existence" in the workplace and in society. The formation of a digital axiology of pre-retirees determines their labor behavior. Therefore, we can make a statement about the transformation of social and labor relations arising under the influence of digitalization. Successful implementation of this task requires adaptation of pre-retirees to the constantly changing conditions of digitalization.

In general, studies have shown that, in comparison with generations $\mathrm{Z}$ and $Y$, digitalization is not one of the basic values (values-ways) among preretirees but is another change in the environment to which it is necessary to adapt and adapt. Accordingly, the digital axiology of pre-retirees is in the stage of formation.

To implement the outlined institutional reforms in Russia, it is necessary to continue the outlined course for the development of digital literacy and digital skills, especially for workers of pre-retirement age, thereby forming a digital axiology of pre-retirees.

\section{Acknowledgments}

The study was conducted in the framework of the RFBR grant No. 19010-00362 A. JEL: J11; J53.

\section{Bibliographic References}

ALBANESE, Andrea; COCKX, Bart. 2019. "Permanent wage cost subsidies for older workers. An effective tool for employment retention and postponing early retirement?” In: Labour Economics.Vol. 58, pp. 145-166. 
Apenko Svetlana Nikolaevna, Kiriliuk Olga Mikhailovna, Legchilina Elena Yurevna y Tsalko Tatiana Valerevna

662

Study of The Transformation of Social and Labor Relations in The Conditions of Pension Reform: Aspect of Digital Axiology

ANSHINA, Marina. 2019. Indigenous people of the digital world and digital emigrants. IT Manager. Available online. In: https://www.it-world.ru/ cionews/want/148611.html. Consultation date: 19/12/2019.

APENKO, Svetlana; KIRILIUK, Olga Mikhailovna; LEGCHILINA, Elena Yurievna; TSALKO, Tatiana Valerievna. 2019. "Methodology for assessing the impact of the pension reform of the Russian Federation on social and labour relations, economic growth and quality of life of the population" In: Fundamental research. No. 11, pp. 21-30

APENKO, Svetlana N; KIRILIUK, Olga Mikhailovna; LEGCHILINA, Elena Yurievna; TSALKO, Tatiana Valerievna. 2020. "Research of digital axiology of pre-retirees in the conditions of transformation of social and labor relations and pension reform in Russia" In: Labour economics. Vol. 7, No. 10, pp. 967-978.

BAKUMENKO, Lyudmila P; MININA, Elizabeth A. 2020. "International index of digital economy and society (I-DESI): trends in the development of digital technologies" In: Statistics and Economics. Vol. 17, No. 2, pp. 40-54. Available online. In: https://statecon.rea.ru/jour/article/ view/1464/1228. Consultation date: 11/08/2020.

BERSIN, Josh; CHAMORRO-PREMUZIC, Tomas. 2019. The Case for Hiring Older Workers. Available online. In: https://hbr.org/2019/o9/the-casefor-hiring-older-workers. Consultation date: 19/12/2019.

BUCHELE, Robert; CHRISTIANSEN, Jens. 1999. "Labor Relations and Productivity Growth in Advanced Capitalist Economies" In: Review of Radical Political Economics. Vol. 31, No. 1, pp 87-110.

CARLSSONA, Magnus; ERIKSSON Stefan. 2019. "Age discrimination in hiring decisions: Evidence from a field experiment in the labor market" In: Labour Economics. Vol. 59, pp. 173-183. Available online. In: https:// www.sciencedirect.com/science/article/abs/pii/So927537119300259. Consultation date: 19/12/2019.

GKS.RU. 2019. Comprehensive Monitoring Of The Population's Living Conditions. Available online. In: https://www.gks.ru/free_doc/new_ site/KOUZ18/index.html. Consultation date: 19/12/2019.

CUTCHER-GERSHENFELD, Joel; ISAAC, Joe. 2018. "Creating value and mitigating harm: Assessing institutional objectives in Australian industrial relations" In: The Economic and Labour Relations Review. Vol. 29, No. 2. Available online. In: http://journals.sagepub.com/doi/ full/10.1177/1035304618767263. Consultation date: 19/12/2019. 
DECREE OF THE PRESIDENT OF THE RUSSIAN FEDERATION. 2020. «On national development goals of the Russian Federation for the period up to 2030». No. 474 of July 21. Available online. In: http://publication. pravo.gov.ru/Document/View/oo01202007210012. Consultation date: 11/o8/2020.

DIGITAL ECONOMY INDICATORS. 2019. Statistical Handbook. M. NIU VShE. Available online. In: https://www.hse.ru/ data/2019/05/17/1507390400/ice2019kr_en.pdf. Consultation date: 11/08/2020.

ETGETON, Stefan. 2018. "The effect of pension reforms on old-age income inequality" In: Labour Economics. Vol. 53, pp, 146-161. Available online. In: https://www.sciencedirect.com/science/article/abs/pii/ So927537118300538. Consultation date: 19/12/2019.

GEYER, Johannes; HAAN, Peter; HAMMERSCHMID, Anna; PETERS, Michael. 2020. "Labor Market and Distributional Effects of an Increase in the Retirement Age" In: Labour Economics. Vol. 65. Available online. In: https://www.sciencedirect.com/science/article/abs/pii/ So927537120300233. Consultation date: 05/09/2020.

GORLIN, Yuriy M; LYASHOK, Victor Yu; MALEVA, Tatyana M. 2018. “Raising the retirement age: positive effects and probable risks” In: Economic policy. No. 1, pp. 148-178.

HELFEN, Markus;SCHÜßLER, Elke; SYDOW, Jörg. 2018. "How can employment relations in global value networks be managed towards social responsibility? In: Human Relations. Available online. In: http://journals.sagepub.com/doi/full/10.1177/0018726718757060. Consultation date: 19/12/2019.

HOWE, John. 2017. "Labour regulation now and in the future: Current trends and emerging themes" In: Journal of Industrial Relations. Vol. 59, No. 2, pp. 209-224.

KULAKOVA, Anna B. 2018. "Generation Z: theoretical aspect” In: Territorial development issues. Vol. 42, No. 2, p.6 (in Russian).

LEGCHILINA, Elena Yurievna. 2019. "Designing of social and labor relations in the context of transformation: principles, organizational and institutional aspects” In: Amazonia Investiga. Vol. 8, No. 21, pp. 326-333. Available online. In:__ https://amazoniainvestiga.info/index.php/amazonia/ article/view/109. Consultation date: 19/12/2019.

LEGCHILINA, Elena Yurievna. 2020. “The impact of changes in labor relations on mortality rates in Russia” In: Amazonia Investiga. Vol. 9, No. 26, pp. 
Apenko Svetlana Nikolaevna, Kiriliuk Olga Mikhailovna, Legchilina Elena Yurevna y Tsalko Tatiana Valerevna

664

Study of The Transformation of Social and Labor Relations in The Conditions of Pension Reform:

Aspect of Digital Axiology

36-51. Available online. In: https://amazoniainvestiga.info/index.php/ amazonia/article/view/1105. Consultation date: 11/08/2020.

LLOYD, Delia. 2018. 21st Century Skills for Older WorkersWork. Available online. In: https://www.ageing.ox.ac.uk/blog/skills-for-older-workers. Consultation date: 19/12/2019.

MEDVEDEVA, Tatiana A. 2013. "Investigation of the processes of transformation of social and labor relations on the basis of an extended systematic approach" Vestnik NSU. In: Series. Socio-economic sciences. No. $13 / 4$, pp. 172-180.

NATIONAL INDEX OF DEVELOPMENT OF THE DIGITAL ECONOMY. 2018. Goskorporatsiya Rosatom. Moscow, Russia (in Russian).

NEHODA, Evgeniya V. 2013. Social and labor relations: research results in Russia and Ukraine. L. V. Bezzubko, E. V. Nehoda. Tomsk State University. Tomsk, Russia.

OZHIGANOVA, E.M. 2015. "Straus Howe generational theory. Opportunities of practical application" In: Business education in the knowledge economy. Vol. 1, No, 1, pp. 94-97 (in Russian).

POLOVINKO, Vladimir Semenovich. 2015. "Modernization of social and labor relations in the period of neo-industrialization" In: Bulletin of Omsk University. Series "Economics”. No. 3, pp. 9-13

ROKEACH, Milton. 1973. The Nature of Human Values. Free Press. New York, USA.

SÁNCHEZ-ROMERO, Miguel; SAMBT, Jože; PRSKAWETZ, Alexia. 2013."Quantifying the role of alternative pension reforms on the Austrian economy” In: Labour Economics. Vol. 22, pp. 94-114.

SHAMIS, Evgeniya; ANTIPOV, A. 2016. The theory of generations. Synergy Institute. San Fernando, Trinidad and Tobago.

SOLOVIEV, Arkady Konstantinovich. 2015. "Demographic conditions for raising the retirement age in Russia" In: Population. No. 2, pp. 39-51.

STEPANOVA, Tatyana Borisovna; TRISHINA, O. Yu. 2019. Baby boomers and homelanders: finding ways to interact. Collection of scientific articles. Current issues of fundamental Sciences in a technical University. Kemerovo, Russia.

STUKEN, Tatiana; KORZHOVA, Olga. 2019. "Strategic personnel management: context of retirement age reform in Russia” In: Strategic Management. Vol. 4, No. 24, pp. 21-27. 
TIMOFEEV, Alexander Vadimovic. 2019. Formation of digital axiology: key concepts and problems. In: Bulletin of the Moscow state University. Series: Philosophical Sciences. Moscow, Russia.

THE CONCEPT OF DIGITAL TRANSFORMATION OF PJSC ROSSETI 2030. 2018. Electronic resource. Available online. In: https://www.rosseti. ru/investment/Kontseptsiya_Tsifrovaya_transformatsiya_2030.pdf. Consultation date: 19/12/2019.

VIGTEL, Trond Christian. 2018. "The retirement age and the hiring of senior workers" In: Labour Economics, Volume 51, pp. 247-270. Available online. In: https://www.sciencedirect.com/science/article/pii/ So927537117302221. Consultation date: 19/12/2019.

ZHUKOVSKAYA, Irina Feodosievna. 2018. "Pension System of Russia: Reforms and Problems" In: Economics and Management: Problems, Solutions. Vol. 2, No. 4, p. 21-30. 

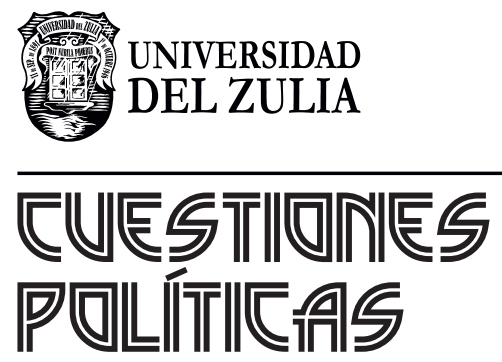

Vol.39 No 68

Esta revista fue editada en formato digital y publicada en enero de 2021, por el Fondo Editorial Serbiluz, Universidad del Zulia. Maracaibo-Venezuela 